\title{
Article
}

\section{Time for practice; sport and the environment}

\author{
Carmichael, Andrew
}

Available at http://clok.uclan.ac.uk/33390/

Carmichael, Andrew ORCID: 0000-0001-9540-2114 (2020) Time for practice; sport and the environment. Managing Sport and Leisure . pp. 1-10. ISSN 23750472

It is advisable to refer to the publisher's version if you intend to cite from the work. http://dx.doi.org/10.1080/23750472.2020.1757493

For more information about UCLan's research in this area go to http://www.uclan.ac.uk/researchgroups/ and search for < name of research Group>.

For information about Research generally at UCLan please go to http://www.uclan.ac.uk/research/

All outputs in CLoK are protected by Intellectual Property Rights law, including Copyright law. Copyright, IPR and Moral Rights for the works on this site are retained by the individual authors and/or other copyright owners. Terms and conditions for use of this material are defined in the policies page.

\section{CLoK}

Central Lancashire online Knowledge www.clok.uclan.ac.uk

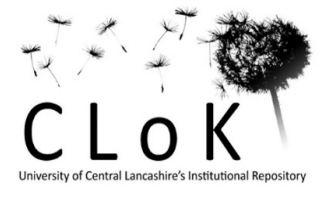


Time for Practice; Sport and the Environment 


\section{Time for Practice; Sport and the Environment}

The sport and environment literature is small, utilises a limited number of theoretical positions and ignores the work on social practice theory developed in other disciplines. The oversights in existing research are often compounded by reference to the broad term of sustainability and the use of case studies from the minority - elite, professional, organisations - in the sport sector. This commentary identifies the need for additional research on the mitigation of sport's environmental impact using different interpretations of how we define, organise and play sport. Expanding the discussion would allow sport to play a more active role in the fundamental lifestyle changes necessitated by the environmental crisis.

Keywords: sport; environment; behaviour; social practice theory 


\section{Introduction}

The benefits of sports facilities are clear, they serve a valuable social, environmental and economic function in local communities and offer recreation, the potential for health improvement and a quality of life aspect for individuals (Strandberg, Blombäck, Dahl Jensen \& Knox, 2012). However, such provision comes at a price. Sport registers significant and measurable impacts on the environment (McCullough, Pfahl \& Nguyen, 2016), and the hosting of sport has been linked to ecological damage such as a decline in air and water quality, a decrease in habitats and a reduction of species (Mansfield, 2009). At a time when the environment is already under pressure; from climate change (IPCC, 2018), population growth (Urry, 2010) and the demands of economic development (Victor, 2010), sport encompasses all aspects of the environmental debate. Scientific methods lie at the heart of its management of land and water to produce conditions for play and commercial activity throughout its levels of organisation. Sport reaches large populations and offers a highly visible stage for promoting messages that seek to influence followers' actions (Casper \& Pfahl, 2015). It is also a politicised series of cultural practices that offer historical and sociological meaning (Horne, Tomlinson \& Whannel, 1999). As such, sport offers a highly relevant, contextually significant, and required, forum for examining solutions to environmental problems that could provide insight for other sectors of society.

Consequently, it might be expected to find a comprehensive sport and environment literature. Instead, discussion of sport and environmental activity is in its relative infancy and offers the potential for expansion. Mallen, Stevens and Adams (2011) undertook a content analysis of 21 sport-focused, refereed journals (1987 to 2008), finding only $17(0.37 \% \mathrm{n}=4639)$ research articles focused on, the broad term of, 
'environmental sustainability'. Since 2008 there has been a growing academic interest in sport and the environment, research now encompassing the legacies of major sporting events such as the Olympic Games to the footprint of smaller individual sports (such as golf), team based facilities and the behaviour of those concerned (Karamichas, 2013; Mansfield \& Wheaton, 2011; Millington \& Wilson, 2016). Moreover, there has been pressure on sport and its governing bodies by the United Nations Framework Convention on Climate Change to engage with its aims and become environmentally responsible (Trendafilova \& McCullough, 2018). Sport is now specifically included in the United Nations (UN) Sustainable Development Goals (SDGs) agenda (Millington, Darnell \& Millington, 2018) and there are a number of industry bodies (BASIS, Green Sports Alliance, Surfers Against Sewage) dedicated to improving the environmental performance of their sector.

Yet, a revised analysis (Mallen, 2018), using the same parameters as the previous study (Mallen, Stevens and Adams, 2011), identified only 53 additional articles published on the subject in seven years. Dingle (2016) undertook a similar exercise to Mallen (2018) and identified just 51 new articles since 2008. Trendadilova and McCullough (2018, p.3) published "a rapid review" of literature to determine "if environmental sustainability research addressed the current efforts of the sport sector". Their study considered journals listed with the North American Society for Sport Management (NASSM) between 2007 and the end of September 2017, finding 84 articles. Compared with Mallen (2018) and Dingle's (2016) analysis this adds $n=31$ and $n=33$ publications to the list from an additional two-year period. However, Trendafilova and McCullough (2018, p.10) conclude that "when one looks at the numbers, it is clear that more scholarly work is necessary if we are to keep up with the efforts of the sport sector when 
it comes to environmental sustainability". In contrast to other aspects of sport, there remain "multiple gaps in the literature" rendering the understanding of sport and environmental sustainability "incomplete" (Mallen, 2018, p.22).

This incomplete understanding of environmental activity in sport is further challenged by the terminology used in some of the literature. All three of the literature reviews identified (Dingle, 2016; Mallen, 2018; Trendafilova \& McCullough, 2018) refer to environmental sustainability. The word 'sustainable' is contentious and to describe an activity as being undertaken 'sustainably' assumes that it is possible to perform that activity without additional impact on resources. This is a key debate in the environmental literature, and there are opposing views of whether such things are possible (Millington \& Wilson, 2016). A 'sustainability' approach, based on the theory of ecological modernisation, has been utilised towards a 'business friendly' strategy, or 'light green' attitude to the task (Millington \& Wilson, 2016). For example, the idea that environmental damage can be reduced as consumers exercise their choice to purchase less harmful products, which inspires innovation by manufacturers to improve their product and company standing. Contrary to this is the 'dark green' concept, that holds that there are inequalities in prioritising economics as the solution to ecological problems and that the elements of 'triple bottom line' (a framework for identifying the social, environmental and economic concerns associated with business activity) should not be treated equally as environmental considerations need to be given prominence (Millington \& Wilson, 2016). This then begs the question of what is meant by 'green', a term Chernushenko (1994) suggests as being the lowest, or as near as possible, level of environmental impact currently achievable. This implies there is only one state of 'green', a measurable quantity, it cannot be broadly 'light' or 'dark'. Consequently, use of these terms in research should be very clear. Yet, 
the absence of such clarity in some of the existing work in the sport environment literature shows that "green is up for grabs" (Miller, 2017, p.15).

This commentary identifies that not only is the sport and environment literature small and at times comparatively lacking in definition, its focus is relatively narrow. Though climate change demands fundamental transformation of our lives (Anderson, 2015; IPCC, 2018; Shove, 2010a) I explain that current research into sport and the environment is yet to address the scale of the challenge or the opportunities for remedial action. There are theoretical perspectives in the environmental literature that could support work in the field of sport that are little, or never, mentioned. Both Mallen (2018) and Dingle (2016) catalogued the type of paper that had been published, concluding that quantitative method-based studies are increasing in popularity. While the range of theoretical bases has broadened in more recent work, Dingle (2016) noted the decline in sociological theory papers, with only two publications on sport and the environment in sport sociology journals. Most of the current approaches in the discipline utilise a highly select few positions, particularly those that promote individual behaviour as the solution to environmental issues in sport. These are often supported by studies of, and evidence from, the elite and spectacular of the sector, the mega-events and professional organisations at the apex of the sporting pyramid. I conclude that there is a need to broaden the debate in sport, reflecting developments in the general environmental literature, using evidence from a more inclusive interpretation of what constitutes 'sport'. 


\section{Behavioural Interpretations of Pro-Environmental Activity}

Discussion of individual behaviour within pro-environmental activity is often framed with reference to a model, typically comprising one of three general approaches; behaviour viewed as a function of processes and characteristics internal to the individual (for example, attitudes, values, habits and personal norms), external to the individual (such as fiscal and regulatory incentives, institutional constraints and social norms) or a combination of both internal and external features (Jackson, 2005).

Yet the relevance of such factors to pro-environmental behaviour is disputed due to contrasting evidence from studies, for example, on the role of affluence (Larson, Whiting \& Green, 2011), gender (Torgler \& Garcia-Valinas, 2007), and education (Meyer, 2015). Taking, for instance, the attempt to change behaviour through the use of pricing, incentives and taxation it is argued that the existing economic position of individuals is a significant influence on their environmental behaviour, with the protection of the environment being a 'good' and demand for it rising with income (Torgler \& Garcia-Valinas, 2007). Yet, there is evidence, that demand for this 'good' will be lower if the costs of pro-environmental activity are monetarily higher than alternatives, and in fact a lack of income may lead to more positive activity as it could preclude environmentally damaging activities such as driving a car (Hobman \& Frederiks, 2014). As Turaga, Howarth and Borsuk (2010) note there are divergent positions throughout the literature with philosophical and methodological bases so contrary to each other as to offer little by way of common ground. Indeed, the inconsistency in individuals' environmental behaviour, and the existence of a 'valueaction gap' (Blake, 1999) that sees expressions fail to become activity, may continue to generate different positions on causes of that behaviour (Steg \& Vlek, 2009). 
Attempting to explain some of these contradictions there is an approach to combine internal and external factors of models and place them within the social and cultural context in which an individual exists. Stern's (2000) 'attitude-behaviour-context' model (ABC), for example, outlines how "environmentally significant behaviour" is a matter of attitudinal factors (attitudes, norms, habits), personal capabilities, routine and the provisions and constrictions of the situation (for example, infrastructure, technology and legal concerns).

\section{Criticism of Behavioural Approaches}

Whether they view the influences on behaviour as being either internal, external or something of both, what the models have in common is that they believe that behaviour is a force at the heart of activity, to be acted upon, influenced, nudged or changed. Criticism aimed at these socio-psychological models is more fundamental than simple neglect of internal and external factors or context, such models are considered by some as being too individualistic, too rationalist and insufficiently critical of the status quo of neoliberal and consumerist socio-economic systems (Hargreaves, 2011). Shove (2010a, p.1274) highlights the 'ABC' model in particular as adopting a political position that obscures " the extent to which governments sustain unsustainable economic institutions and ways of life, and the extent to which they have a hand in structuring options and possibilities". Showing how reports may vary in emphasis, yet still place individual behaviour as central to the problem with mutual referencing providing support for such claims, Shove argues (2010a, 2010b) that this thinking relegates the policy options to an expensive and risk-laden list of possible influences on individual choice and how best to increase the efficiency of 'good' decisions. When the authors of the individual-centric 
models include context, they are not essentially changing the approach, they are merely offering retrospective consideration for why initial ideas may have failed.

\section{Beyond Behaviour - Social Practice Theory}

Social practice theory developed from the ideas of the philosophers Heidegger, Wittgenstein and the sociological works of Bourdieu, Giddens, Foucault and Butler (Halkier, Katz-Gerro \& Martens, 2011). The unit of analysis is not the individual but the practice, a concept summarised by Reckwitz (2002, p.249) as; "a routinized type of behaviour which consists of several elements, interconnected to one another: forms of bodily activities, forms of mental activities, 'things' and their use, a background knowledge in the form of understanding, know-how, states of emotion and motivational knowledge". Pantzar and Shove (2015) construct the idea that there are three elements to a practice; materials (objects that allow for a practice), meanings (concepts that determine how and when a practice may be performed) and procedures or competences (abilities that allow for a practice). Taking the environmental example of water use, Hand, Shove and Southerton (2005) showed how in the practice of showering that the relationship between these elements has evolved, to create what is now a habitualised, daily routine of using a shower for many, and highlights the resource-intensive, highly consumptive lives that the challenges of climate change need us to be abandoning. There is clear evidence of this practice shift within sport, for example football abandoning the communal bath for participants after matches in favour of individual cleanliness, showering and privacy (FA, 2011). That makes social practice theory particularly insightful in any study of environmental interactions in sport, with its mass participation and a reliance on landscape for its activity and chimes with Casper and Pfahl's (2015, p.4) suggestion to "examine the natural environment and sport from a 
broad and holistic perspective". Research published both within, and since, Mallen's (2018) analysis of journal articles is yet to achieve this ambition.

\section{Reviewing the Field}

The focus of some of the existing sport-based work is observation of the environmental impacts of sport (Casper \& Bunds, 2017, Casper, Pfahl \& McSherry, 2012; Collins \& Flynn, 2008; Mallen, Stevens, Adams \& McRoberts, 2010; Phillips \& Turner, 2014). These are surveys, interviews, case studies and measurements, akin to an audit of the state of a sport, organisation or event. A number of other studies seek to make the behaviour of consumers of the sport the focus, identifying how their actions may be influenced by the sport or sports venue they attend rather than examining the wider environmental implications of hosting the sport (Baldwin, 2010; Brymer, Downey \& Gray, 2009; Inoue \& Kent, 2012; McCullough, 2013; McCullough \& Kellison, 2016). Other work (Bunds, et al., 2018; Dolf \& Teehan, 2015) link the two, identifying that the behaviour of spectators attending the sporting event causes significant impacts on the environment.

That there is "a dominant line of reasoning reinforced by extensive mutual crossreferencing" within the environment literature (Shove, 2010a, p.1274), seems particularly apposite to the sport environment literature. The starting point for much of the work is that there are confirmed antecedents of what is a behavioural issue and the question of what is required to 'correct' a lack of pro-environmental activity has largely been resolved. The premise appears to be that individual sport managers can make decisions that will impact the environment and other considerations are offered more, as Shove highlights (2010a) of the behavioural approach, as contextual influences on the 
choices they will make. This highly selective interpretation of the challenge is reflected in a chapter by Inoue (2015, p.14) outlining the "theoretical foundations for understanding the pro-environmental behaviour of individuals involved in sport" in the work Sport Management and the Environment (Casper \& Pfahl, 2015). In its ten pages it focuses largely on theories dating to the last century; the theory of reasoned action (Fishbein \& Ajzen, 1975), the theory of planned behaviour (Azjen, 1988, 1991; Azjen \& Fishbein, 1980; Azjen \& Madden, 1986) and the value-belief-norm theory (Stern, Dietz, Abel, Guagnano, \& Kalof, 1999). This despite the earlier identification of contradictory evidence bases and little agreement on the efficacy of models. This seems typical of the sport environment literature, that it is derived from a sports agenda seeking to find sense in individual ideas rather than a deeper examination of the environmental discussion as applied to sport. The volume and importance of work produced since the last of these theories cannot be ignored in any serious discussion of the subject. Yet, in what seems the rush to introduce case studies of well-known sports teams and venues seeming to engage in 'good practice', that appears to be exactly what is happening.

It would be useful to provide greater recognition of the deficiencies that have been shown in behavioural models. These models promote the status quo, a narrative of sport that promotes the benefits of increased participation and a celebration of skills, transferring the burden of environmental damage mitigation onto individuals. The climate challenge is so great that we need to be asking bigger questions of how we live our lives. What do we expect, how do we consume, and how do we organise? Despite the understanding that the issues associated with climate change and natural resource depletion are so significant as to prompt investigation of new ways of living (Shove, 
2010a) it seems the sport literature is yet to address the deeper questions, such as that posed by Thibault (2009) about what we are prepared to give up to protect sport, let alone what sport is prepared to give up to protect the environment.

Sport environment research often compounds its theoretical oversight by illustrating behavioural strategies with reference to case studies from the minority, the elite, professional, organisations in the sport sector. Where there is examination of motivations or influences on environmental activity in a sport the subjects of study are often large scale or well-resourced bodies (Babiak \& Trendafilova, 2011; Kellison \& Hong, 2015; Mallen et al., 2010a; Peachey \& Bruening, 2011). The Routledge Handbook of Sport and Politics (Bairner, Kelly \& Lee, 2017) illustrates its brief chapter on 'Sport and Sustainability' with a case study of the Centre Court at the All England Club, Wimbledon (Atkinson, 2017). McCullough and Kellison (2018) begin their introduction to the Routledge Handbook of Sport and the Environment by positioning pro-environmental activity with reference to the professional National Hockey League, individual behaviour change and the few sport organisations who have integrated environmentally responsible policies in their operations, the first example given being the International Olympic Committee (IOC). Indeed, the IOC is regularly mentioned in sport and pro-environmental activity work (Casper, Pfahl \& McSherry, 2012; Mallen et al., 2011; Mallen \& Chard, 2011; Millington, Darnell \& Millington, 2018; Paquette, Stevens \& Mallen, 2011; Thibault, 2009; Trendafilova, et al., 2014). Considering how few journal articles there are on the subject this is disproportionate, even for a megaevent as significant as the Olympic games, when compared with the relative impact of sport on the environment every day of the week. 
Clearly there are environmental issues with the travel of large numbers of spectators to such events and offsetting the emissions caused by this is regularly identified as a goal in mitigation planning by hosts of the event. This focus would help account for why studies have prioritised this aspect of sport and sought to understand behavioural modelling to propose solutions. However, elite competitions remain a very narrow definition of sport (and an even narrower measurement of global travel and emissions). Where studies have positioned themselves as examining travelling, or consumption, behaviour of non-elite sport spectators as a significant factor (Casper, Pfahl \& McCullough, 2017; Dolf \& Teehan, 2015; McCullough, 2013; Triantafyllidis, Ries, \& Kaplanidou, 2018) the evidence bases they use are North American collegiate organisations. These are still well-resourced bodies, often occupying large stadiums and attracting thousands of fans. When air travel to matches is mentioned as a significant factor towards the environmental footprint of the event (Dolf \& Teehan, 2015) it is evident this is a very different level of 'community sport' than witnessed by, for example, most of the 29,000 football clubs in England. Far more insightful for considering the impacts of these organisations would be the study by Wicker (2019b) of the travel arrangements of participants in community sports.

This continued exemplification of the elite ignores the experience and context of many of the non-professional organisations that offer the greatest challenges, but also opportunities, for reducing resource consumption, improving landscapes, and lowering the environmental impact of their sport. We need to be asking where all sport fits into the world envisaged by the UN SDGs. More research needs to be directed towards the scale of the non-professional, community-based sports sector and their impact on the environment. While the general pro-environmental activity debate considers the 
reactions of large populations, for example the city of Buenos Aires (Jakovcevic et al., 2014), Spain (Torgler \& Garcia-Valinas, 2007) and Europe (Meyer, 2015), the sport environment research largely confines itself to discussions based on data from a very small group. This focus seems to assume that the masses can be inspired to change by example from the top, a trickle-down of information mobilising a bottom-up movement of cleaner, greener sport. There are studies of local, and largely voluntary, sports bodies (Findlay-King, Nichols, Forbes, \& MacFadyen, 2018; Parnell, May, Widdop, Cope \& Bailey, 2019; Wicker 2019a) but they have different research aims and the consequence for the environment of these organisations' work is not within their scope. Examination of the social practices pertaining to these clubs would offer a broader perspective of the relationships between activities and what may be indirect environmental damage, and identify that at this level the few spectators that there are do not provide the greatest threat to the landscape. As Miller (2016, p.2) notes, football may seem "among the least ecologically malevolent of pastimes" but broadening the analysis to include where and how materials are made, the management of the field and the energy that sustains the sport changes the assessment.

Future research in sport needs to not only increase the study of sport environment interactions but identify how we can address the negative consequences of the games we play on a scale that matches the extent of the crisis. We need to examine not just nature and sport but the nature of sport to do this. If individual behaviour modelling is to continue to provide the theoretical basis of some work, then it should be tested at a level of sport representative of the majority that participate. This level is not the Olympics, professional teams or college stadiums hosting tens of thousands of visitors but smaller communities of voluntary sport. Alternatives to these behavioural models 
need to be considered. Social practice theory with its examination of the relationships between the components of an activity is ideally positioned to do this and a sport such as Association Football would be an ideal vehicle for analysing the deeper relationships highlighted by Miller (2016). In utilising social practices as a theoretical position, sport would be joining subjects such as consumer behaviour, health and social policy (Halkier et al., 2011) and would demonstrate that it was prepared to consider change on a scale that could have a long-lasting and profound legacy.

\section{References}

Ajzen, I. (1988). From Intentions to Actions: A Theory of Planned Behaviour. In Kuhl, J. \& Beckmann, J. (Eds.) Action-Control: From Cognition to Behaviour (pp. 11-39). Heidelberg: Springer.

Ajzen, I. (1991). The Theory of Planned Behavior. Organizational Behavior and Human Decision Processes, 50, 179-211. doi.org/10.1016/0749-5978(91)90020-T

Ajzen, I. \& Fishbein, M. (1980). Understanding Attitudes and Predicting Social Behaviour. New Jersey: Prentice-Hall Inc.

Ajzen, I. \& Madden, T. (1986). Predictions of Goal-Directed Behaviour: Attitudes, Intentions and Perceived Behavioral Control. Journal of Experimental Social Psychology, 22, 453-474. doi.org/10.1016/0022-1031(86)90045-4 
Anderson, K. (2015). Duality in Climate Science, Nature Geoscience, 8, 898-900 doi.org/10.1038/ngeo2559

Atkinson, W. (2017). Sport and Sustainability. In Bairner, A, Kelly, J, \& Lee, J.W. (Eds.) Routledge Handbook of Sport and Politics (pp.359-371). Routledge: London.

Babiak, K. \& Trendafilova, S. (2011). CSR and Environmental Responsibility: Motives and Pressures to Adopt Green Management Practices. Corporate Social Responsibility and Environmental Management, 18, 11-24. doi.org/10.1002/csr.229

Bairner, A., Kelly, J. \& Lee, J.W. (2017). Routledge Handbook of Sport and Politics. London: Routledge.

Baldwin, R. (2010). Football and Climate Change: Strange Bedfellows or a Means of Going Beyond the Usual Suspects in Encouraging Pro-Environmental Behavioural Change? Local Environment, 15, 851-866. doi.org/10.1080/13549839.2010.531252

Blake, J. (1999). Overcoming the Value Action Gap in Environmental Policy: Tensions Between National Policy and Local Experience. Local Environment, 4, 257-278. doi.org/10.1080/13549839908725599

Bunds, K. S., Kanters, M. A., Venditti, R. A., Rajagopalan, N., Casper, J. M., \& Carlton, T. A. (2018). Organized Youth Sports and Commuting Behavior: The Environmental Impact of Decentralized Community Sport Facilities. Transportation 
Research Part D: Transport and Environment, 65, 387-395.

doi.org/10.1016/j.trd.2018.08.017

Brymer, E., Downey, G. \& Gray, T. (2009). Extreme Sports as a Precursor to Environmental Sustainability. Journal of Sport \& Tourism, 14, 193-204.

doi.org/10.1080/14775080902965223

Casper, J.M., \& Bunds, K.S. (2017). Tailgating and Air Quality. In B. McCullough \& T.B. Kellison (Eds.) Handbook on Sport, Sustainability, and the Environment, (pp.291-300). New York, NY: Routledge.

Casper, J.M, Pfahl, M., \& McCullough, B. P. (2017). Is Going Green Worth It? Assessing Fan Engagement and Perceptions of Athletic Department Environmental Efforts. Journal of Applied Sport Management, 9 (1), 106-134. doi:10.18666/JASM2017-V9-I1-7690

Casper, J.M. \& Pfahl, M.E. (2015). Sport and the Natural Environment. In Casper, J.M \& Pfahl, M.E. (Eds). Sport Management and the Natural Environment, Theory and Practice (pp.3-14). Oxford: Routledge.

Casper. J, Pfahl, M. \& McSherry, M. (2012). Athletics Department Awareness and Action Regarding the Environment: A Study of NCAA Athletics Department Sustainability Practices. Journal of Sport Management, 26, 11-29. doi.org/10.1123/jsm.26.1.11 
Chernushenko, D. (1994). Greening Our Games. Ottawa: Centurion.

Collins, A.J. \& Flynn, A. (2008). Measuring the Environmental Sustainability of a Major Sporting Event: A Case Study of the FA Cup Final. Tourism Economics, 14 (4), 751-768. doi.org/10.5367/000000008786440120

Dingle. G. (2016). Sport, the Natural Environment, and Sustainability. In Hoye, R. \& Parent, M.M. (Eds), SAGE Handbook of Sport Management (pp.531-558). UK: SAGE.

Dolf. M, \& Teehan. P. (2015). Reducing the Carbon Footprint of Spectator and Team Travel at The University of British Columbia's Varsity Sports Events. Sport Management Review, 18 (2), 244-255. doi.org/10.1016/j.smr.2014.06.003

FA. (2011). Best Practice Guidance - Changing Rooms and Showering Facilities. Retrieved from http://www.thefa.com

Findlay-King, L., Nichols, G., Forbes, D. \& MacFadyen, G. (2018). Localism and the Big Society: The Asset Transfer of Leisure Centres and Libraries - Fighting Closures or Empowering Communities? Leisure Studies, 37, 158-170. doi.org/10.1080/02614367.2017.1285954

Fishbein, M., \& Ajzen, I. (1975). Belief, Attitude, Intention, and Behavior. Reading, MA: Addison-Wesley. 
Halkier, B., Katz-Gerro. T. \& Martens, L. (2011). Applying Practice Theory to the Study of Consumption: Theoretical and Methodological Considerations. Journal of Consumer Culture, 11 (1), 3-13. doi.org/10.1177/1469540510391765

Hand, M., Shove, E. \& Southerton, D. (2005). Explaining Showering: A Discussion of the Material, Conventional, and Temporal Dimensions of Practice. Sociological Research Online, 10 (2). doi.org/10.5153/sro.1100

Hargreaves, T. (2011). Practice-Ing Behaviour Change: Applying Social Practice Theory to Pro-Environmental Behaviour Change. Journal of Consumer Culture, 11, (1), 79-99. doi.org/10.1177/1469540510390500

Hobman. E. \& Frederiks. E. (2014). Barriers to Green Electricity Subscription in Australia: "Love the Environment, Love Renewable Energy...But Why Should I Pay More?” Energy Research \& Social Science, 3, 78-88.

doi.org/10.1016/j.erss.2014.07.009

Horne, J., Tomlinson, A., \& Whannel, G. (1999). Understanding Sport. An Introduction to the Sociological and Cultural Analysis of Sport. London: Routledge.

Inoue, Y. (2015). Theoretical Foundations for Understanding Pro Environmental Behaviour in Sport. In Casper, J.M \& Pfahl, M.E (Eds.) Sport Management and the Natural Environment, Theory and Practice (pp.14-28). Oxford: Routledge. 
Inoue, Y. \& Kent, A. (2012). Sport Teams as Promoters of Pro-Environmental Behavior: An Empirical Study. Journal of Sport Management, 26, 417-432. doi.org/ 10.1123/jsm.26.5.417

IPCC, 2018: Summary for Policymakers. In: Global Warming of $1.5^{\circ} \mathrm{C}$. An IPCC Special Report on the Impacts of Global Warming of $1.5^{\circ} \mathrm{C}$ Above Pre-Industrial Levels and Related Global Greenhouse Gas Emission Pathways, In The Context Of Strengthening The Global Response to the Threat Of Climate Change, Sustainable Development, and Efforts to Eradicate Poverty [Masson-Delmotte, V., P. Zhai, H.-O. Pörtner, D. Roberts, J. Skea, P.R. Shukla, A. Pirani, W. Moufouma-Okia, C. Péan, R. Pidcock, S. Connors, J.B.R. Matthews, Y. Chen, X. Zhou, M.I. Gomis, E. Lonnoy, T. Maycock, M. Tignor, and T. Waterfield (eds.)]. World Meteorological Organization, Geneva, Switzerland. Retrieved from https://www.ipcc.ch/sr15/

Jackson. T. (2005). Motivating Sustainable Consumption; a Review of Evidence on Consumer Behaviour and Behavioural Change. A Report to the Sustainable Development Research Network. Retrieved from http://www.sustainablelifestyles.ac.uk

Jakovcevic, A., Steg, L., Mazzeo, N., Caballero, R., Franco, P., Putrino, N. \& Favara, J. (2014). Charges for Plastic Bags: Motivational and Behavioral Effects. Journal of Environmental Psychology, 40, 372-380. doi.org/10.1016/j.jenvp.2014.09.004

Karamichas, J. (2013). The Olympic Games and the Environment. London: Palgrave Macmillan. 
Kellison, T. B. \& Hong, S. (2015). The Adoption and Diffusion of Pro-Environmental Stadium Design. European Sport Management Quarterly, 15 (2), 249-269. doi.org/10.1080/16184742.2014.995690

Larson, L.R., Whiting, J.W., \& Green, G.T (2011). Exploring the Influence of Outdoor Recreation Participation on Pro-Environmental Behaviour in a Demographically Diverse Population. Local Environment, 16 (1), 67-86.

doi.org/10.1080/13549839.2010.548373

McCullough, B.P. (2013). Identifying the Influences on Sport Spectator Recycling Behaviours Using the Theory of Planned Behaviour. International Journal of Sport Management and Marketing, 14 (1/2/3/4), 146-168.

doi.org/10.1504/IJSMM.2013.0606

McCullough, B. P \& Kellison, T.B. (2018). An Introduction to Environmental Sustainability and Sport. In McCullough, B. P \& Kellison, T.B (Eds.) Routledge Handbook of Sport and the Environment (pp.1-10). Oxford: Routledge.

McCullough, B. P., \& Kellison, T. B. (2016). Go Green for The Home Team: Sense of Place and Environmental Sustainability in Sport. Journal of Sustainability Education, 1-14. 
McCullough, B.P., Pfahl, M.E. \& Nguyen, S. (2016). The Green Waves of Environmental Sustainability in Sport. Sport in Society, 19, 1040-1065. doi.org/10.1080/17430437.2015.10962511

Mallen, C. (2018). Robustness of the Sport and Environmental Sustainability Literature and Where to Go from Here. In McCullough, B. P. \& Kellison, T.B. (Eds.) Routledge Handbook of Sport and the Environment (pp.11-35). Oxford: Routledge.

Mallen, C., Adams, L., Stevens, J. \& Thompson, L. (2010a). Environmental Sustainability in Sport Facility Management: A Delphi Study. European Sport Management Quarterly, 10, 367-389. doi.org/10.1080/16184741003774521

Mallen, C. \& Chard, C. (2011). A Framework for Debating the Future of Environmental Sustainability in the Sport Academy. Sport Management Review, 14, 424-433. doi.org/10.1016/j.smr.2010.12.002

Mallen, C., Stevens, J., Adams, L. \& McRoberts, S. (2010). The Assessment of the Environmental Performance of an International Multi-Sport Event. European Sport Management Quarterly, 10 (1), 97-122. doi.org/10.1080/16184740903460488

Mallen, C., Stevens, J. \& Adams, L. (2011). A Content Analysis of Environmental Sustainability Research in a Sport-Related Journal Sample. Journal of Sport Management, 25, 240-256. doi.org/10.1123/jsm.25.3.240 
Mansfield, L. (2009). Fitness Cultures and Environmental (In)Justice? International Review for the Sociology of Sport, 44 (4), 345-362.

doi.org/10.1177/1012690209343029

Mansfield, L. \& Wheaton, B. (2011). Leisure and the Politics of the Environment, Leisure Studies, 30 (4), 383-386. doi.org/10.1080/02614367.2011.626916

Meyer, A. (2015). Does Education Increase Pro-Environmental Behavior? Evidence from Europe. Ecological Economics, 116, 108-121.

doi.org/10.1016/j.ecolecon.2015.04.018

Millington, R., Darnell, S.C., \& Millington, B. (2018). Ecological Modernization and the Olympics: The Case of Golf and Rio's “Green” Games. Sociology of Sport Journal, 35, 8-16. doi.org/10.1123/ssj.2016-0131

Millington, B. \& Wilson, B. (2016). The Greening of Golf: Sport, Globalization and the Environment. Manchester, U.K: Manchester University Press.

Miller, T. (2017). Greenwashing Sport. Oxford: Routledge.

Miller, T. (2016): Greenwashed Sports and Environmental Activism: Formula 1 and FIFA, Environmental Communication, doi:10.1080/17524032.2015.1127850 
Pantzar, M \& Shove, E. (2015). The Choreography of Everyday Life. Retrieved from https://www.lancaster.ac.uk/staff/shove/choreography/front.htm

Paquette, J., Stevens, J. \& Mallen, C. (2011). The Interpretation of Environmental Sustainability by the International Olympic Committee and Organizing Committees of the Olympic Games from 1994 to 2008. Sport in Society: Cultures, Commerce, Media, Politics, 14, 355-369. doi.org/10.1080/17430437.2011.557272

Parnell, D., May, A., Widdop, P., Cope, E. \& Bailey, R. (2019). Management Strategies of Non-Profit Community Sport Facilities in an Era of Austerity, European Sport Management Quarterly, 19:3, 312-330, doi:10.1080/16184742.2018.1523944

Peachey, J.W. \& Bruening, J. (2011). An Examination of Environmental Forces Driving Change and Stakeholder Responses in a Football Championship Subdivision Athletic Department. Sport Management Review, 14, 202-219.

doi.org/10.1016/j.smr.2010.09.002

Phillips, P. \& Turner P. (2014). Water Management in Sport. Sport Management Review, 17, 376-389. doi.org/10.1016/j.smr.2013.08.002

Reckwitz, A. (2002). Toward A Theory of Social Practices. A Development in Culturalist Theorizing. European Journal of Social Theory, 5, 243-263. doi.org/10.1177/13684310222225432 
Shove, E. (2010a). Beyond the ABC: Climate Change Policy and Theories of Social Change. Environment and Planning A, 42, 1273-1285. doi.org/10.1068/a42282

Shove, E. (2010b). Submission to the House of Lords Science and Technology Select Committee Call for Evidence on Behaviour Change. Submitted in a Personal Capacity, 7 October 2010. Retrieved from https://www.lancaster.ac.uk/staff/shove

Steg. L. \& Vlek. C. (2009). Encouraging Pro-Environmental Behaviour: An Integrative Review and Research Agenda. Journal of Environmental Psychology, 29, 309-317. doi.org/10.1016/j.jenvp.2008.10.004

Stern, P. (2000). Toward a Coherent Theory of Environmentally Significant Behavior. Journal of Social Issues, 56, 407-424. doi.org/10.1111/0022-4537.00175

Stern, P., Dietz, T., Abel, T., Guagnano, G. \& Kalof, L. (1999). A Value-Belief Norm Theory of Support for Social Movements: The Case of Environmental Concern. Human Ecology Review, 6, 81-97. Retrieved from https://cedar.wwu.edu/hcop_facpubs/1

Strandberg, M., Blombäck, K., Dahl Jensen, A.M. \& Knox, J.W. (2012). Priorities for Sustainable Turfgrass Management: A Research and Industry Perspective. Acta Agriculturae Scandinavica, Section B - Soil \& Plant Science, 62 (1), 3-9. doi.org/10.1080/09064710.2012.682163 
Thibault, L. (2009). Globalization of Sport: An Inconvenient Truth. Journal of Sport Management, 23, 1-20. Retrieved from https://journals.humankinetics.com

Torgler, B. \& García-Valiñas, M. (2007). The Determinants of Individuals' Attitudes Towards Preventing Environmental Damage. Ecological Economics, 63, 536-552. doi.org/10.1016/j.ecolecon.2006.12.013

Trendafilova, S. \& McCullough, B.P. (2018). Environmental Sustainability Scholarship and the Efforts of the Sport Sector: A Rapid Review of Literature. Cogent Social Sciences, $4: 1$. Retrieved from https://www.tandfonline.com

Trendafilova, S., McCullough, B., Pfahl, M., Nguyen, S.N., Casper, J. \& Picariello, M. (2014). Environmental Sustainability in Sport: Current State and Future Trends. Global Journal on Advances in Pure \& Applied Sciences, 3, 9-14. Retrieved from https://www.icsspe.org

Triantafyllidis, S., Ries, R. J., \& Kaplanidou, K. (2018). Carbon Dioxide Emissions of Spectators' Transportation in Collegiate Sporting Events: Comparing On-Campus and Off-Campus Stadium Locations. Sustainability, 10 (241), 1-18. doi.org/10.3390/su10010241

Turaga. R.M.R., Howarth. R.B. \& Borsuk. M.E. (2010). Pro-Environmental Behavior; Rational Choice Meets Moral Motivation. Annals of New York Academy of Science, 1185, 211-224. doi.org/10.1111/j.1749-6632.2009.05163.x 
Urry, J. (2010). Consuming the Planet to Excess, Theory, Culture and Society, 27, 191212. doi: $10.1177 / 0263276409355999$

Victor, P. (2010). Questioning Economic Growth. Nature, 468, 370-371.

doi.org/10.1038/468370a

Wicker, P. (2019a). Volunteering in Sports Clubs and its Impacts. In Downward, P., Frick, B., Humphreys, B. R., Pawlowski, T., Ruseski, J.E., \& Soebbing, B. P. (Eds) The SAGE Handbook of Sports Economics, (pp. 92-101). UK: Sage doi.org/10.4135/9781526470447

Wicker, P. (2019b). The Carbon Footprint of Active Sport Participants. Sport Management Review, 22 (4), 513-526. doi.org/10.1016/j.smr.2018.07.001 